\title{
In the days of print: Four women journalists in World War II
}

PATRICIA CLARKE

Early in 1943 at a critical point in the Pacific campaign in World War II, the Australian Government arranged a tour for selected women journalists to operational bases in eastern Australia stretching from Wagga Wagga and Uranquinty in south-western New South Wales to Cairns and Mareeba in north Queensland. The purpose of the tour was to gain publicity for the women's services with the aim of increasing enlistments to release servicemen to fight in New Guinea. It was a break from government policy under which women journalists were confined to reporting war activities situated close to the headquarters of the organisations they worked for. But it was still a far cry from accrediting women journalists to report from overseas battlefields, a goal they had long pursued without success.

The 8 women nominated for the tour came from the major daily newspapers and magazines in Sydney and Melbourne-from the serious broadsheets to the popular tabloids and the women's magazines. They were Constance (Connie) Robertson who represented the Sydney Morning Herald, Melbourne Age and the Australian Broadcasting Commission (ABC); Iris Dexter, Woman; Alice Jackson, Australian Women's Weekly; Rita Dunstan, Sydney Daily Telegraph; Patricia Knox, Melbourne Argus, Adelaide Advertiser and Examiner; Kathleen (Kay) Paine, Sydney Sun and Melbourne Herald; Chrissie (Mrs Laurie) Seaman, Sydney Daily Mirror; and Helen (Nell) McMahon, Melbourne Sun-News Pictorial. Lieutenant Lynka Isaacson, a veteran journalist serving with the Australian Women's Army Service, was in charge of the tour.

The 4 women who are the subject of detailed analysis in this article are Constance Robertson and Patricia Knox, who represented the daily papers of record in Sydney and Melbourne respectively; Iris Dexter, who represented a weekly women's magazine on nationwide sale; and Lynka Isaacson, who had been a senior journalist on the weekly Leader and from the beginning of the war was foreign editor of the Age. They all earned their living in a career where women were a small minority and they were working women when, even in wartime, less than one-third of females over 14 years (the school-leaving age) were in the workforce or in the services. ${ }^{1}$

1 Paul Hasluck, The Government and the People 1942-1945 (Canberra: Australian War Memorial, 1965), 221-22. At 30 June 1943, only 29.9 per cent of Australian females over 14 were employed or in the services. The comparable figure for males over 14 was 89.6 per cent. 
Each of their life stories is unique, collectively they are part of the social history of Australia. Robertson and Dexter began work in their early to mid-teens; Isaacson had the background and confidence to go straight to the managing editor of the Age, Geoffrey Syme, to ask for a job; and Knox had the advantage of being a daughter of the managing director of the Argus. Under the journalists' award they were all paid at the same rate as male journalists in an era when most working women were paid only a percentage of male rates, but this was largely negated through gender discrimination in the restricted range of jobs open to them. ${ }^{2}$ Discrimination extended to the law. In the mid-1930s Dexter was denied a divorce although the judge accepted that she had been subject to repeated violent attacks by her husband.

These random facts plucked from 4 life stories raise questions about, for example, the education system, the varied paths into journalism, employment standards and pay, and the divorce laws. A study of their working lives points to the status of women reporters in the hierarchy of journalists, the historic reasons for the genderbased discrimination against women journalists, the efforts women made to be accepted on an equal basis with male colleagues and the disparaging attitude to female colleagues intrinsic to most male journalists of the era. It also considers the different histories, characteristics and policies of the publications the women wrote for, whether this influenced what and how they wrote, and the different skills required to write for dailies and weeklies.

\section{Background}

During World War II, despite strenuous efforts by women journalists, the Department of Information backed by military authorities maintained a ban that prevented them from travelling overseas to report the war from battlefields. This invidious position was in striking contrast to the Boer War at which Australia had a woman correspondent, Edith Dickenson, who reported for the Adelaide Advertiser. ${ }^{3}$ She was a forerunner of Australian women war correspondents and was not equalled for many years. In World War I, Louise Mack, a former editor of the Bulletin's women's page, became the first British female war correspondent when she reported firsthand the German invasion of Belgium, ${ }^{4}$ and Katharine Susannah Prichard reported on Australian nurses and the casualties they nursed in a war hospital on the French coast, ${ }^{5}$ but no other Australian women reporters got near the frontline.

2 Jeannine Baker, 'Australian Women Journalists and the "Pretence of Equality", Labour History, no. 108 (May 2015): 1-16.

3 Patricia Clarke, 'Australia’s First Female War Correspondent: Edith Dickenson at the Boer War', in Reporting from the Wars 1850-2015: The Origins and Evolution of the War Correspondent, ed. B. Turner, D. Barredo and S.J. Grattan (Wilmington, Delaware: Vernon Press, 2018), 39-62.

4 Patricia Clarke, Pen Portraits: Women Writers and Journalists in Nineteenth-Century Australia (North Sydney: Allen \& Unwin, 1988), 234-37.

5 Katharine Susannah Prichard, 'Best Hospital at the Front', Sunday Times (Sydney), 28 February 1915, suppl., 1. 
In 1941 Constance Robertson, editor of the Sydney Morning Herald's women's department, sought permission to go to the Middle East to report on war work being undertaken by women in World War II. She gained some support from the Minister for the Army, Percy Spender, who in passing on her request to the Minister for Information, Senator Harry Foll, said that her proposal had 'substance and merit'. He acknowledged, however, the ban the government had imposed on 'womenfolk engaged on work of this nature proceeding to theatres of war'. The Department of Information supported Spender's request, but Foll was adamant. Although he acknowledged that the press would welcome a woman's angle on the life of Australian women on active service, he believed 'our official correspondents' could cover all assignments 'including the work of the nurses and the V.A.D.s' ${ }^{6}$ All Australia's official correspondents throughout World War II were male. Women journalists continued to be banned from reporting not only from overseas fronts but also from Australia's northern cities and towns even in 1942 at the height of the Pacific War when Australian troops were fighting on the Kokoda Track to keep Japanese forces from taking Port Moresby and Japanese planes were bombing Darwin, Townsville and Broome. They were confined to reporting how women were contributing to the war effort on the home front close to the head offices of their organisations. ${ }^{?}$

In October 1942, the prime minister, John Curtin, announced, as part of a comprehensive plan to make the best use of manpower (the universally used term for men and women in this context), that the government was preparing for a compulsory call-up of women for national service to release men for combat. ${ }^{8}$ Women were needed in manufacturing and rural sectors of the economy as well as in the services. They had begun to enlist in the Australian Women's Army Service (AWAS), Women's Auxiliary Australian Air Force (WAAAF) and Women's Royal Australian Naval Service (WRANS) from the time they were formed in 1941, but both the AWAS and the WAAAF needed 5,000 more women to enlist towards their immediate targets of 20,000 each. ${ }^{9}$

Brigadier Errol Knox the director general of Army Public Relations, a wartime position he held concurrently with his role as managing director of the Melbourne newspaper group the Argus \& Australasian Ltd, saw the opportunity to use the skills of women journalists to help in this objective. The result was the plan for a conducted tour by accredited women correspondents from 8 February to 11 March

\footnotetext{
6 National Archives of Australia (NAA) SP112/1, 353/3/18, barcode 26832, Proposal to send Mrs Constance Robertson overseas to cover activities of Australian women in War Work.

$7 \quad$ NAA SP112/1, M 101, barcode 935116, Accredited War Correspondents, p. 48.

8 'Women Will Be Called Up. New Man-Power Drive. Longer Work Hours', Sydney Morning Herald, 16 October 1942,5 .

$9 \quad$ 'Services Need More Women', Examiner (Launceston), 28 January 1943, 3.
} 
1943 covering operational bases in New South Wales and Queensland. At all the bases members of the women's services were replacing men in specialist occupations previously regarded as men's work. ${ }^{10}$

\section{Importance of news in wartime}

In 1943 daily newspapers, weekly periodicals, radio bulletins and newsreels were the main sources of news and, in wartime, access to news was important for the functioning of daily life. Home delivery of morning papers was widespread, evening papers were widely read in cities on the homeward trip on trains and trams, and city dwellers who did not buy papers could hardly avoid the pervasiveness of news posters, the cries of newsboys and displays at news kiosks. News reached country people, who were out of reach of the dailies, through the weekly editions of the major city dailies. The Sydney Mail had a wide circulation in country New South Wales while the Australasian, the stable mate of the Argus, and the Leader, which was associated with the Age, provided a choice for Victorian country readers, and there were similar weekly editions in other states. Although radio stations ran frequent news broadcasts, often hourly, the contents were compiled from news agencies, official bulletins and press reports supported by some actuality broadcasts. ${ }^{11}$ Even the ABC did not have a completely independent news service until 1 June 1947.

Newspapers and magazines were also widely used by the government for 'their ability to raise funds and disseminate wartime propaganda', ${ }^{12}$ and they carried much government advertising to encourage recruitment and raise money through War bonds and other means. The Australian Women's Weekly was credited with playing a key role in maintaining morale on the home front, adopting slogans such as 'Make do and mend' and 'Keep the home fires burning. ${ }^{13}$ Its value to the government lay in its circulation, which rose from about 0.25 million in 1935 to 0.5 million in the early war years; by the end of the war, in a population of about 7 million, it sold 650,000 copies a week. ${ }^{14}$ Each copy was believed to be read by most members of a household and often forwarded to those serving in the armed forces. Newsprint was rationed for all publications, a cause of constant complaints of unfair allocations.

10 NAA SP109/3 395/04, barcode 267070. Tour by Accredited Women Correspondents, 4-7.

11 Bridget Griffen-Foley, Changing Stations: The Story of Australian Commercial Radio (Sydney: UNSW Press, 2009), 318-33.

12 Bridget Griffen-Foley, 'The Fairfax, Murdoch and Packer Dynasties in Twentieth-Century Australia', Media History 8, no. 1 (2002): 94.

13 Griffen-Foley, 'Fairfax, Murdoch and Packer', 94.

14 Helena Studdert, 'Case-Study Women's Magazines', in A History of the Book in Australia 1891-1945, ed. Martin Lyons and John Arnold (St Lucia, Qld: University of Queensland Press, 2001), 281; 'The Australian Women's Weekly. Depression and the War Years. Romance and Reality', Refractory Girl, Winter 1973, 9. 
It resulted in the Sydney Daily and Sunday Telegraphs changing from broadsheet to tabloid size in 1942, although the Sydney Morning Herald, the Age and the Argus and similar dailies in other states remained broadsheets.

\section{Tour by accredited women war correspondents}

Although no doubt flattered by their designation as war correspondents and issued with shoulder flashes in green and gold reading 'War Correspondent' to wear on their Army issue uniforms, the journalists chosen for the tour were aware that it was a propaganda trip and they were expected to fulfil a particular role. At least some of them would have believed it was a poor substitute for getting to New Guinea and other battlefields. Although they were reporting from within Australia, the locations of their articles were never disclosed; all their dispatches were headed 'Somewhere in Australia'. Their articles were subject to 3 levels of censorship in a similar way to stories originating in New Guinea. They were sent first to Melbourne to the censorship headquarters of the Department of Information that exercised civilian censorship, then to Defence censorship headquarters also in Melbourne. After that, 'if deemed necessary', they were subjected to further censorship at General MacArthur's South West Pacific Allied Headquarters located in Brisbane; although in the case of the women journalists' articles, arrangements were made to delegate this third step to a representative in Melbourne. ${ }^{15}$

Iris Dexter decided the tour was a good subject for gentle satire. Each week, in addition to her articles as a senior reporter on Woman, she wrote a weekly column under the pseudonym 'Margot Parker', in which she took a humorous look at the foibles of personal relationships and at the public's rather bemused adaptation to war regulations as they impeded more and more on daily life. The tour presented her with a new subject in the experiences of her invented friend, Frenzia Frisby, recently accredited war correspondent. She introduced Frenzia puffed up with importance, as she prepared to leave for 'Somewhere in Australia'.

For a long while I have put up with Frenzia, The Girl Reporter. This indicates my devotion and tolerance. But I feel now, with this Frightening New Turn the war has taken, that I can no longer cope with Frenzia The War Correspondent.

My eyes have assumed a blazing green incandescence because I am not the one to be dashing around in khaki officers' uniforms, hobnobbing with Squadron Leaders, looking important in Staff Cars and setting the jaw interminably.

15 E.G. Bonney, Chief Publicity Censor to State Publicity Censor, TP Hoey, 3 February 1943; Hoey to Bonney, Parliament House, Canberra, 6 February 1943, NAA SP109/3, 395/04, Tour by Accredited Women Correspondents; John Hilvert, Blue Pencil Warriors: Censorship and Propaganda in World War II (St Lucia, Qld: University of Queensland Press, 1984), 146. 
As she travelled around the city with Frenzia, who immediately cast her in the role of batman, she observed her becoming sterner and more military:

She began calling trams Transport immediately, and got into them very gravely, twitching her jaw muscles at people and looking as though She Knew Something They Didn't Know ... ${ }^{16}$

The group's crowded itinerary ranged from night flying training operations at a wartime airfield at Uranquinty near Wagga Wagga in inland New South Wales, the Balmoral naval base and Concord Military Hospital in Sydney, observation and defence installations along the New South Wales coast to the steelworks at Newcastle. Their Queensland itinerary took in Macarthur's headquarters in Brisbane, war industries in Toowoomba, the garrison city of Townsville and the leave centre on Magnetic Island, hospitals and leave centres throughout north Queensland, Mareeba on the Atherton Tableland, and coastal defences around Cairns. By chance, the group was inspecting a far northern coastal defence outpost in the first week of March 1943 while the battle of the Bismarck Sea was under way. They watched in the control room as WAAAF personnel plotted the course of the battle, a pivotal naval engagement of the Pacific War that ended Japanese hopes of regaining the initiative in New Guinea and eliminated any possibility that Australia could be invaded. On the situation maps and blackboards around the room the journalists saw 'the complete story at a glance of the war in the South West Pacific'. Patricia Knox described the scene:

In one of the largest operational rooms of the Air Force in the North of Australia I watched WAAAFs at work. I saw them write on a board the details of a certain operational mission - the mission that day was the Bismarck Sea. Later I saw the first reports come in from the aircraft_-'Two ships left burning' and we knew that the RAAF had found its target. It is from these rooms that the history of the war in the air is written. ${ }^{17}$

\section{Caroline (Lynka) Isaacson}

The tour began when the journalists converged by train from Sydney and Melbourne at Wagga Wagga where Lieutenant Lynka Isaacson met them together with WAAAF Section Officer Hunter and Lynka's daughter, AWAS Private Barbara Joan Isaacson, who was assigned as a photographer. ${ }^{18}$ It was a tour that required all Isaacson's experience and organisational and interpersonal skills in addition to her knowledge of the diverse roles of women in the services and what would or would not pass the censors. A talented and versatile woman who had succeeded in several branches of journalism at a time when there were few opportunities open to women, she was suited to the challenge.

16 Margot Parker, 'Uniform Makes the Woman', Woman, 22 March 1943, 9.

17 Patricia Knox, 'Women Can Keep Secrets', Argus, 5 April 1943, 6.

18 NAA VF391191, B884, barcode 6237011, Isaacson, Barbara Joan. 


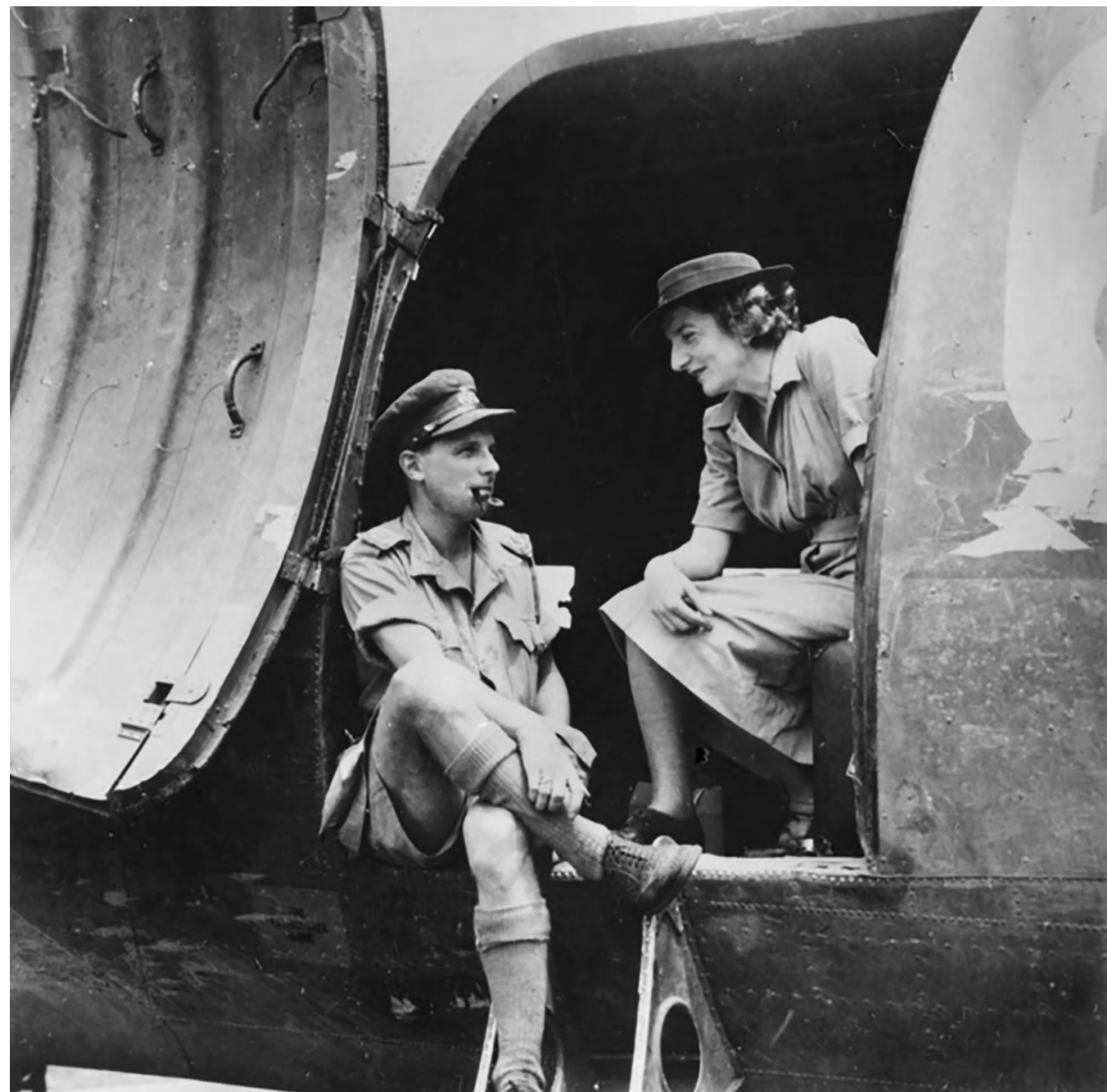

Figure 1: Lt Lynka Isaacson, Directorate of Army Public Relations, and liaison officer Captain Henry Steel during a tour by women journalists to Queensland and the Atherton Tableland in March 1943.

Source: Pte Barbara Joan Isaacson (Australian War Memorial PO5161.013).

Born Caroline Jacobson in Vienna on 14 September 1900, a daughter of a director the Royal Holland Shipping Line and a French mother, and always known by her childhood pet name of Lynka (even enlisting in the Australian Army under that name), she had a cosmopolitan education and spoke 7 languages. At age 18, she had just enrolled in a medical course in London when she met Australian-born Lieutenant Arnold Isaacson, 37, a commercial traveller in Victoria before World War I, who had seen service with the Australian Imperial Force (AIF) at Gallipoli, 
the Middle East and France. ${ }^{19} \mathrm{~A}$ few months after they met they were married on 30 March 1919 at Dalston Synagogue, Islington. Two children were born in London before the family migrated to Melbourne in $1926 .{ }^{20}$

After her husband's business as an importer's agent failed in 1928, and although she had no newspaper experience, Lynka went straight to the top approaching Geoffrey Syme, managing editor of the Age, to ask for work on the women's pages. Her confident manner, her stylish appearance and her contacts in Melbourne society won the day, and she progressed quickly to editor of the women's pages of the Leader, the rural weekly associated with the Age. During the 1930s she developed the section by encouraging readers to contribute household hints to 'The Spare Corner' column that became so popular she edited several editions of selected contributions for publication. ${ }^{21} \mathrm{~A}$ frequent speaker at country events, she gathered a community of followers who flocked to Melbourne for annual picnics she organised. In the early part of World War II, when male journalists began to enlist in the forces, she moved to the post of foreign editor of the Age, a job that would have been well out of the reach of a woman in peacetime.

During the 1930s, Isaacson was active in moves to resettle Jewish refugees from Nazi Germany and she supported the Freeland League for Jewish Territorial Colonization that sought a homeland for persecuted European Jews. At first the League's plans involved a vast tract of land in the East Kimberley, but when that was ruled out by the Australian Government, the remote south-west of Tasmania, now the Tasmanian Wilderness World Heritage Area, was favoured. In pursuit of this scheme Isaacson became associated with an idealistic young man, Critchley Parker Jnr, whose death from starvation and exposure occurred while he was attempting to map the outline of the proposed Jewish settlement in the rugged, mountainous south-west of the state. His letters and journal addressed to Lynka were found near his body at the foot of Mt Mackenzie near Bathurst Harbour. ${ }^{22}$

Deeply affected by this tragedy, Isaacson abandoned her hard-won position at the Age and enlisted in the AWAS as a private in August 1942, putting her age back 2 years to come within the enlistment range. She was promoted rapidly through the ranks and by the beginning of 1943 was a lieutenant (at times acting captain) in

19 NAA B2455, barcode 7368134, Isaacson, Arnold, Lieutenant.

20 Denis Warner, The Pathfinder: In the Air-on the Ground: The Peter Isaacson Story (Melbourne: Information Australia, 2000), 15-16, 23-4.

21 The Leader Spare Corner Book: A Unique Collection of Home and Household Hints and Kitchen Recipes: For Australian Women (Melbourne: David Syme \& Co., published in many editions, 1929 to 1940).

22 Harold A. Freeman, 'The Charismatic Caroline Isaacson', Australian Jewish Historical Society Journal XVIII, part 4 (2007): 506-17; Hilary L. Rubinstein, 'Critchley Parker (1911-1942): Australian Martyr for Jewish Refugees', Australian Jewish Historical Society Journal XI, part 1 (November 1990): 57-64; Critchley Parker Jnr, Transcript of diary/notebook, State Library Victoria (SLV), MS Box 4128/8; I. N. Steinberg, Australia: The Unpromised Land (London: Gollanz, 1948), 133-37. 
the Directorate of Army Public Relations. ${ }^{23}$ She met the journalists as they arrived at Wagga Wagga, those from Melbourne at 0049 and those from Sydney at 0949 on 6 February 1943.

The tour was so circumscribed by a highly controlled and packed itinerary and layers of censorship that it was impossible for one correspondent's story to differ markedly from that of another. Most featured newsworthy young women in the AWAS, WAAAF and WRANS who were being trained to work in specialised technical positions, some highly secret, rather than the bulk of servicewomen who worked as clerks, nursing orderlies, telegraphists, signallers, drivers and in mess rooms and stores. The stories of the more challenging jobs were popular because they were more likely to appeal to young women considering enlisting and who would welcome a change from their unexciting lives and civilian jobs. Newly enlisted servicewomen faced the upheaval of leaving their homes, travelling to places they may not have heard of, perhaps in another state even on the opposite side of the continent, and they were thrust into work that was vastly different from their peacetime occupations. The journalists invariably portrayed them as adaptable, happy and cheerful women even in the most adverse circumstances.

At a northern outpost, Patricia Knox found AWASs, clad in shirts, trousers and tin hats, working in heat so severe that even standing still meant a constant bath of perspiration, yet they were 'sunburnt, bronzed and happy'. ${ }^{24}$ Servicewomen stationed near an airfield where RAAF recruits were taught to fly told Iris Dexter that the responsibility of their work as they 'manned' searchlights or tracked aircraft was the reason they 'wouldn't be doing anything else' despite 'the camouflaged tents, the dust, the flies'. ${ }^{25}$ Young women taking over positions previously done by servicemen were described in gendered language as a matter of course: they manned searchlights and ack-ack guns, they did men's jobs, and even the worldly-wise journalists appeared to accept that a man was always in charge. The ack-ack girls north of Cairns hoped it was only a matter of time before 'the Number One Man (the gun-position officer)' would be a girl. Constance Robertson added:

Indeed, if they had their way, the girls would be operating the guns ... It is inspiring to see these girls, who so short a while ago were in shops, offices and homes, now in the pits doing a skilled job on instruments, the efficient management of which means successful action by the anti-aircraft guns. They all asked for the job because they felt they would be in the thick of things, would really be at battle stations. ${ }^{26}$

23 NAA B884, V388729, barcode 6244809, Isaacson, Lynka Caroline.

24 Patricia Knox, 'AWAS Girls Man AA Instruments', Argus, 31 March 1943, 6.

25 'Iris Dexter Tells of the Women Who Go to War', Woman, 1 March 1943, 14-15.

26 Constance Robertson, 'Girls Guard Coast. Co-operation with A-A Gun Crews', Sydney Morning Herald, 31 March 1943, 11. 
Near Uranquinty, all 3 journalists noted without comment (or any comment they made was censored) that WAAAF servicewomen were padlocked by the male sergeant in charge inside the operational structure where they worked in a secret bush location, because their work was so 'hush hush'. In their former lives, one of the servicewomen was studying animal husbandry, another was a university student in botany, a third was an interior decorator and a fourth was a stenographer. ${ }^{27}$

\section{Connie Robertson: 'An institution in Sydney journalism'}

Constance Robertson suited both the standing and the conservative mould of the Sydney Morning Herald. She was a highly competent and experienced journalist who kept ahead of trends in society, but always within boundaries acceptable to her mainly middle-class readers and the paper's management. She was noted for her quiet manner unlike her predecessor Mrs Vera Hamilton who was known as 'Machine-Gun Kate' because of her commanding presence and incisive speech..$^{28}$ At 48, with a wealth of experience behind her and holding a prize job as head of the women's department of a prestige newspaper, Robertson was an obvious choice for the tour and she became the unofficial leader of the group.

The Sydney Morning Herald was, from the time it began in 1838 as the Sydney Herald, the dominant newspaper in New South Wales. It prided itself on being a Tory or conservative publication that sided with the Protestant ascendancy and the property-owning sectors. John Fairfax, the sole owner from 1853, was described as 'a political conservative, a committed Christian and a deacon of the Congregational church'. After he died in 1877, 'the conservative tradition' he imprinted on the paper continued under his son James Reading Fairfax. It was still alive during the reign of Warwick Fairfax snr (later knighted) from 1930 to 1976, covering the period when Robertson was head of the women's department. Like his predecessors, Fairfax continued their tradition of taking 'their responsibilities as a member of the fourth estate very seriously'. ${ }^{29}$

27 Constance Robertson, 'WAAAFs Work in Secrecy. Locked Up on the Job', Sydney Morning Herald, 25 February $1943,4$.

28 Gavin Souter, Company of Heralds: A Century and a Half of Australian Publishing by John Fairfax Limited and Its Predecessors 1931-1981 (Carlton, Vic.: Melbourne University Press, 1981), 155.

29 Collen Ryan, Fairfax: The Rise and Fall (Carlton, Vic.: The Meigunyah Press, 2013), 2, 4. 


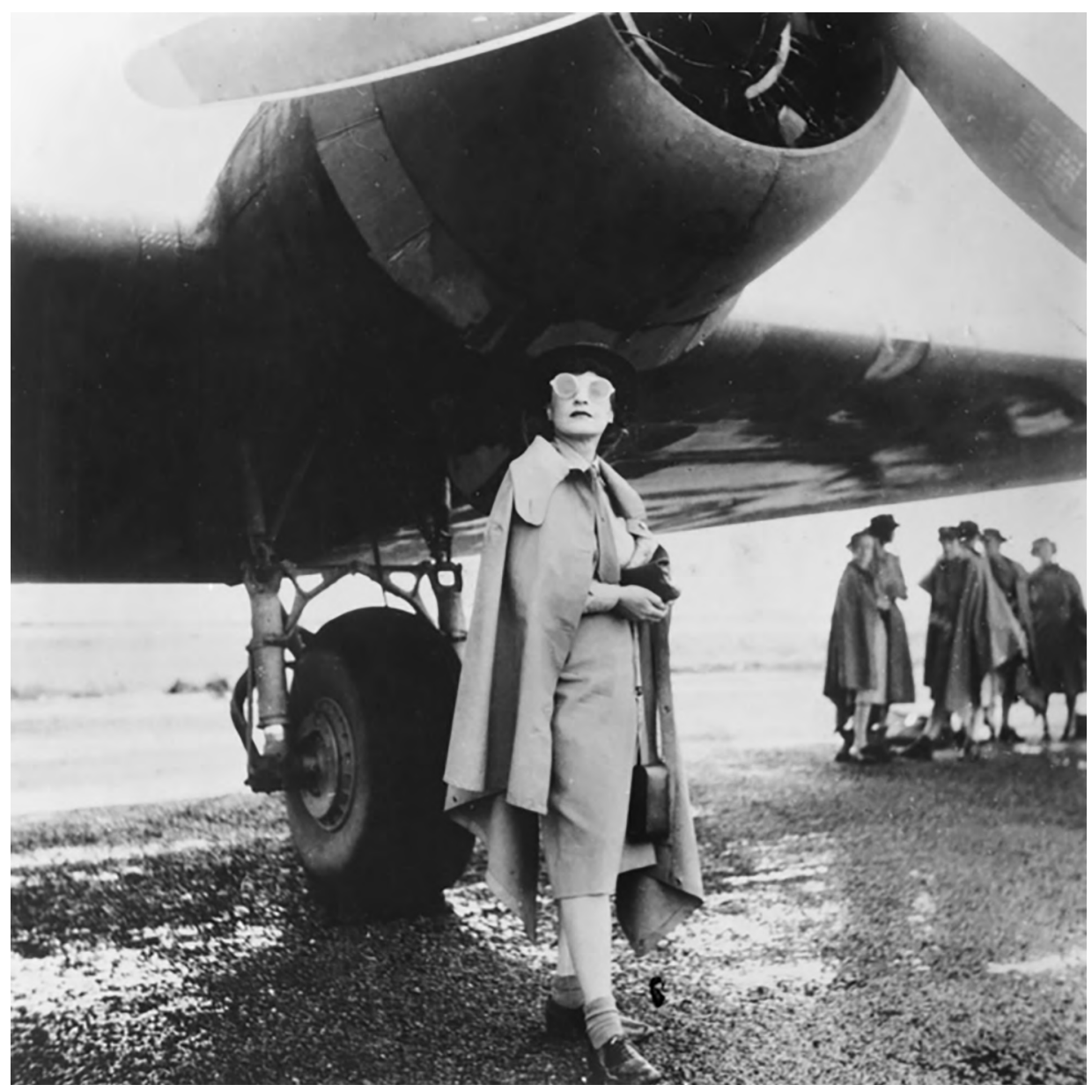

Figure 2: Iris Dexter boarding a Douglas C-47 aircraft during the 1943 women journalists' tour of northern bases.

Source: Pte Barbara Joan Isaacson (Australian War Memorial PO5161.012).

The Sydney Morning Herald was first referred to as 'Granny' in 1851 in the Legislative Council. The name stuck; as newspaper historians Victor Isaacs and Rod Kirkpatrick wrote:

it seemed to suit an institution with very strong views about what was 'right and proper'. Politically the paper espoused the established order. For more than 110 years from its founding it could be relied upon as the upholder of conservative views on politics, society and economics. The firm line represented the views of the Fairfax family, and their editors some of whom in the late nineteenth century were ministers of religion. ${ }^{30}$

30 Victor Isaacs and Rod Kilpatrick, Two Hundred Years of Sydney Newspapers: A Short History (North Richmond, NSW: Rural Press, 2003), 6. 
The paper was also conservative in design, maintaining classified advertisements on its front page until wartime newsprint rationing, as well as the feeling that it was becoming 'old fashioned', forced a redesign. News was placed on the front page for the first time on 15 April $1944 .{ }^{31}$

Constance Robertson suited the Herald. She was competent, responsible and measured, and she had an impeccable journalistic pedigree. She was born in Sydney on 16 October 1895, the eldest child of Constance and Alfred Stephens. Her father, a former editor of country newspapers in Queensland, was then at the beginning of his editorship of the Bulletin's Red Page, which he transformed into the country's most influential and widely read literary outlet. After he left the Bulletin in 1906, he began a literary monthly journal, the Bookfellow, a venture that drained resources from his family and eventually ruined him. Educated by her father, Connie Stephens began work at the Bookfellow, according to her biographer, at the age of 13, running errands, typing and filing, but also observing her father's work in managing contributors and editing and producing the Bookfellow. She met many of Sydney's literary figures, including poet and journalist Mary Gilmore, who partly financed the Bookfellow and who was editor of the Women's Page in the Worker. Gilmore became Connie's model. ${ }^{32}$

When the Bookfellow ceased, Connie Stephens got a job as a proofreader on the afternoon Sydney daily the Sun, but she had picked up enough knowledge of editing at the Bookfellow to take the step into journalism. She became 'social editress' of the popular Sunday Sun and, soon after, she was put in charge of the daily Sun's women's pages and she began the paper's successful women's supplements. The boom years of the 1920s were a good time for women's pages. Backed by increased revenue from advertisements for new appliances and furniture and furnishings for the home and new fashions in clothes, the women's sections of newspapers went from strength to strength. ${ }^{33}$

By 1927 Connie's reputation was so well established she was chosen to represent the women's sections of all Australian evening papers, as one of only 2 women journalists to report the historic opening of Federal Parliament in Canberra. ${ }^{34}$ She retired in 1928 when, at the age of 32, she married sports journalist Bill Robertson, but even on their honeymoon to Hawaii, she covered the first Pan Pacific Women's Conference and her articles made the front page of the Sun. She soon resumed work, continuing until the birth of her only child, a daughter Margot, on 5 June 1929. Six months later she was back at work in a new job as editor of the weekly Woman's

31 Isaacs and Kilpatrick, Two Hundred Years of Sydney Newspapers, 14.

32 Valerie Lawson, Connie Sweetheart: The Story of Connie Robertson (Port Melbourne, Vic.: Willian Heinemann Australia, 1990), 46-57.

33 Clarke, Pen Portraits, 251.

34 The Opinion, June-July 1935, 18. 
Budget, taking her baby with her in a basket that she placed in a filing cabinet drawer while she worked. ${ }^{35}$ When Woman's Budget was incorporated in a new magazine, Woman, established by Associated Newspapers Limited in 1934 to compete with the Australian Women's Weekly begun just the year before, Robertson became editor.

Two years later, she moved to the prestigious position of women's editor of the Sydney Morning Herald where she remained for 26 years, becoming an institution in Sydney journalism. She established a formidable reputation presiding over a staff of 8 who worked under constant pressure to meet her exacting standards while they wrote about society balls and weddings and climbed up rope ladders in their high heels to get stories of celebrities arriving by ship.

Chic, black-haired and quiet, Robertson was a versatile journalist who could turn her hand to all aspects of journalism. She was credited with doing layouts and checking page proofs 'on the stone', a newspaper term for the last stage before the paper was printed. Gavin Souter in his history of the Herald wrote: 'She prided herself on getting hard news as well as "social" news into the women's section and had a flair for recognising and passing on new trends in fashion, home design and cooking. ${ }^{36}$ She included articles on social issues and literary subjects and, reflecting her own and her staffs status as women employed to do skilled work, she featured stories on women performing work usually considered male preserves. Her own life was an example of the paradox in the lives of women journalists of the era: they were working women yet what they wrote was directed at stay-at-home housewives.

Robertson's tour articles portrayed enthusiastic young women cheerfully learning new technical jobs they could hardly have dreamed of in their previous existence as typists, stenographers, milliners and salesgirls, and adapting to communal life in barracks or under canvas in strange parts of Australia often far from their homes and in different climate zones. An article from the early part of the tour about AWAS trainees learning to operate searchlights at an army camp where they were accommodated in tents was typical:

The enthusiasm of these [AWAS] surmounts the heat, the swirling clouds of red dust, the flies, the glare, the mosquitoes, the ants, and even the spiders. ... The girls grin, wipe the red mud packs from their faces, and carry on. They are so busy at their job and so eager to learn that they have no time to use the perfect mirror of the searchlight for make-up. ${ }^{37}$

35 Lawson, Connie Sweetheart, 100.

36 Souter, Company of Heralds, 386.

37 Constance Robertson, 'Army Women Train. Learning to “Man” Searchlights', Sydney Morning Herald,

23 February 1943, 4. 
She also included an observation that would have been reassuring to parents anxious about their daughters stationed on bases where they were greatly outnumbered by men at a time when rumours were spreading of the rate of pregnancy among servicewomen. Young women between the ages of 18 and 21 had to have the consent of a parent or guardian to be accepted in the services. Robertson wrote:

Living quarters vary according to the camp or station where the women are located, but all barracks for members of the WAAAF or the AWAS are in separate compounds all of which are out of bounds to the male personnel of the camp ... Social life is planned on a common basis. Men and women enjoy picnics, sports, dances, picture shows, and concerts together. Romances seem to thrive ... engagements rings are worn with a flourish. ${ }^{38}$

\section{Patricia Knox}

Patricia Knox aged 22 was probably the youngest of the group of women journalists chosen to go on the tour. Whether she was favoured over more senior colleagues on the Argus because of her father's dual roles as managing director of the paper and head of Army Public Relations or not, she would have felt under pressure to prove her value. The Argus demanded high standards from its journalists. The founder of the paper Lauchlan Mackinnon set out to make it an elite newspaper modelled on The Times in London, distinguishing it from its competition the Age that was regarded as 'the workingman's paper'. Until the last few years of its existence when it was acquired by the London Daily Mirror group, the Argus was regarded as the epitome of conservative thinking, but even critics of its 'abject Toryism', such as the foundation editor of the rival Sun News-Pictorial, Montague (Monty) Grover, praised the impeccable quality of its reporting standards. ${ }^{39}$ Readers who detested its conservative opinions were said to buy it for 'its excellent, up to date and thorough handling of its news'. Journalist C. E. (Ted) Sayers, who expressed these views at a symposium on the 'life and death' of the Argus, characterised the paper as 'conservative, comfortably conscious of its leading place in the industry, in the number of its readers, in the quality and scope of its display advertising, and the better-class small classified advertising. ${ }^{40}$

38 Constance Robertson, 'Army in Blue Jeans. Servicewomen at Work and Play', Sydney Morning Herald, 26 February 1943, 7.

39 Montague Grover quoted in Sybil Nolan, 'Manifest Editorial Differences: The Age and The Argus in the 1920s and 1930s', in The Argus: The Life and Death of a Great Melbourne Newspaper 1846-1957, ed. Muriel Porter (Melbourne: RMIT Publishing, 2003), 83-84.

40 C. E. Sayers, quoted in Nolan, 'Manifest Editorial Differences', 85. 


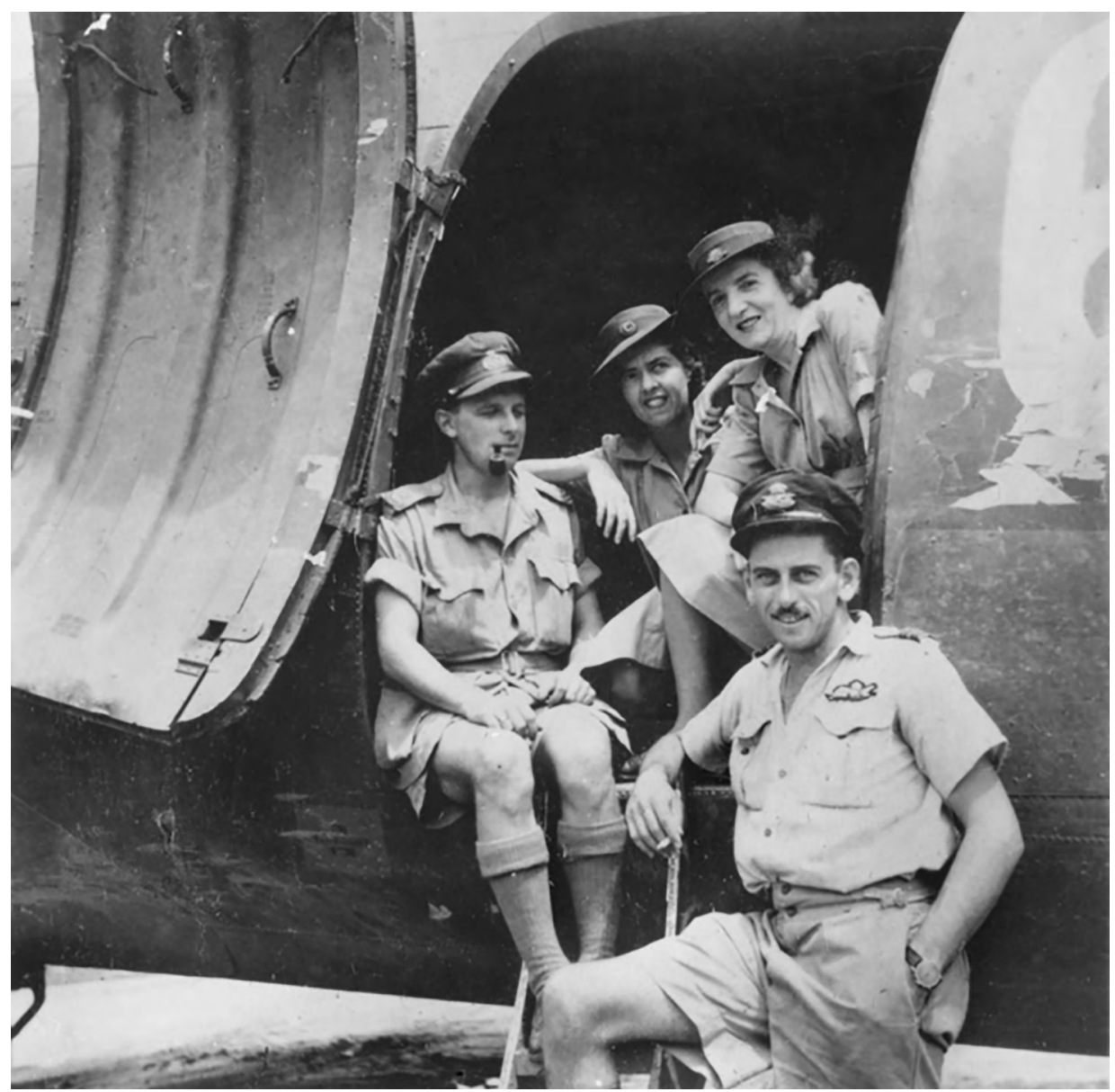

Figure 3: Patricia Knox (centre) who represented the Melbourne Argus on the 1943 tour by women journalists with liaison officer Captain Henry Steel and Lt Lynka Isaacson on board an aircraft.

Source: Pte Barbara Joan Isaacson (Australian War Memorial PO5161.014).

Other journalists made similar points. George Godfrey described it as 'the leading newspaper in Australia', which drew 'tremendous reputation and popular support from the conservative elements in the community. ${ }^{41}$ In peacetime the paper was a fierce opponent of Labor Party policies, but during World War II it supported the Curtin Labor Government. Errol Knox, as managing director, argued that it could do what it liked in its leaders, but that all news items must be strictly objective. During wartime even in editorials 'the Argus and Knox loyally, though not uncritically,

41 George Godfrey quoted in Nolan, 'Manifest Editorial Differences', 84. 
supported the Curtin and then the Chifley government'. ${ }^{22}$ During the war Knox, in his role as head of Army Public Relations, undertook several missions overseas on behalf of the Prime Minister John Curtin and General Douglas MacArthur. ${ }^{43}$

Patricia Monica Knox, was born on 28 September 1920 in Sydney, the eldest child of Errol Galbraith Knox and his English wife, Gertrude Mary Coore, whom he met during his service in World War I. ${ }^{44}$ After enlisting as a private in the AIF, Knox transferred to the Royal Flying Corps where he reached the rank of major and was twice mentioned in dispatches and was appointed MBE. Patricia grew up in Sydney, where her father moved rapidly up the journalistic ladder. From a postwar job with Smith's Weekly, he became news editor of the Sydney Daily Telegraph. In 1922 he was appointed managing editor of the Sydney Evening News and within a year had doubled the paper's circulation. In 1929 he became a director of the newly formed Associated Newspapers Ltd, but resigned two years later when the Evening News closed. During the 1930s Great Depression he had a variety of publishing interests, including editing 2 editions of Who's Who in Australia and 3 editions of the Medical Directory for Australia. ${ }^{45}$ In 1937 the family moved to Melbourne when Errol Knox was appointed managing editor of the Argus \& Australasian Ltd. Three years later he became managing director and was credited with bringing the paper 'to financial strength from a position of collapse'. ${ }^{46}$

The move to Melbourne coincided with Patricia finishing school at Loreto Catholic School for Girls, Kirribilli, Sydney, and she soon had a job as a young journalist on the women's section of the Argus. In 1941-42, as male reporters were called up for war service, she was one of the younger female reporters and some female administrative staff who were moved to general reporting duties, ${ }^{47}$ a move that would have been unlikely for women in peacetime. ${ }^{48}$

Knox's articles on the tour were those of a well-trained reporter so assiduous in sending off stories that it is possible to trace the progress of the tour solely through her articles. The Argus published 22 articles under her byline and its weekly counterpart the Australasian published a much longer, illustrated, wrap-up article. Most of her articles were also republished in one or more New South Wales regional papers including the Northern Star, Lismore; Daily Advertiser, Wagga Wagga; Border

42 A. R. Chisholm, “Knocker” Errol Knox’, in Men Were My Milestones: Australian Portraits and Sketches (Carlton, Vic.: Melbourne University Press, 1958), 134-42.

43 Argus, 18 October 1949, 3.

44 Peter Knox, 'The Knox Family Story', Knoxetal, www.knoxetal.com.

45 Sally O’Neill, 'Knox, Sir Errol Galbraith (1889-1949)', Australian Dictionary of Biography, vol. 9, ed. Bede Nairn and Geoffrey Searle (Carlton, Vic.: Melbourne University Press, 1983), 628-29.

46 'Sir Errol Knox Was Dynamic Figure in Newspaper Industry', Argus, 18 October 1949, 3.

47 Jim Usher, ed., The Argus: Life \& Death of a Newspaper (North Melbourne, Vic.: Australian Scholarly Publishing, 2008), 54.

48 Patricia Clarke, 'Women in the Media', in Companion to the Australian Media, ed. Bridget Griffen-Foley (North Melbourne, Vic.: Australian Scholarly Publishing, 2014), 497. 
Morning Mail, Albury; Daily Examiner, Grafton; Newcastle Morning Herald and Miners' Advocate; Western Grazier, Wilcannia; and in the Nambour Chronicle and North Coast Advocate in Queensland and the Canberra Times in the Australian Capital Territory. Her articles were about 500 to 1,000 words in length.

There was an inevitable similarity between the articles written by journalists on a controlled tour, but, partly because she wrote many more words and partly because of a perceived closer identification with younger servicewomen, Knox's articles had more details of the feminine touches-the flowers in jam jars and the improvised curtains in isolated camps and makeshift quarters. ${ }^{49}$ She was assiduous in noting the civilian jobs of women thrust into very different wartime roles; for example, the milliner who became a first-grade electrical fitter in the WAAAF, the former salesgirl who was vulcanising vital parts of aeroplane engines worn down by constant friction and the former doctor's receptionist who was winding armature coils and testing bomb release machinery. ${ }^{50}$

Although she did not make any comment on gender discrimination, she noted that it was also part of the duties of the WAAAF timekeepers, who checked pilots and planes on night flying training in and out from the airfield, and the WAAAF signals clerks and transport drivers who drove the fire and ambulance vehicles, to make tea and toast for the trainee pilots who were exclusively male. ${ }^{51}$ She also wrote more about servicewomen doing mundane jobs, those who waited on table, helped in the kitchen, made beds and cleaned bedrooms, washed up and did laundry in the officers' clubs. She described them as doing a 'thankless job, and not one to be coveted' in a 'hot and sticky climate amid mosquitoes and flies'. ${ }^{52}$

From the destination 'Somewhere in Australia' in 1943-in fact a street in the Townsville suburb of Mysterton-Knox described one of the more unusual improvisations of the war, the blocking off of a street of Queensland-style stilt houses, the forced evacuation of its inhabitants and the transformation of the houses into the United States Army 12th station hospital:

Two rows of weatherboard houses on opposite sides of a street have been taken over, and the hospital set up in them. The staff has adapted very easily to these unorthodox surroundings. The street is closed at both ends, with large notices reading 'No road' and 'No Thoroughfare' ... The cottages on one side of the street have all been joined by ramps so that patients can be wheeled from one to another. In one is the operating theatre ... On the other side of the street the houses have been left separate. Some are wards, other hospital offices, pathology department, Red Cross recreation room and kitchen and messroom. ${ }^{53}$

49 Patricia Knox, 'Work of WAAAF and AWAS. Living far from Home', Argus, 25 February 1943, 4.

50 Patricia Knox, 'These Girls Do Men's Jobs. Fitter Who Was a Milliner', Argus, 2 March 1943, 6.

51 Patricia Knox, 'Dust and Concerts: WAAAFs at Work and Play', Argus, 26 February 1943, 6.

52 Patricia Knox, 'Messwomen Do Grand Job in North', Argus, 7 April 1943, 10.

53 Patricia Knox, 'From Street to Hospital. Metamorphosis in the North', Argus 10 April 1943, 10. 
During its 2 years' operation, the hospital treated over 23,000 casualties. After it closed the houses were restored before they were returned to their owners who had been given only one week to evacuate as Townsville was transformed into a garrison city early in $1942 .{ }^{54}$

\section{Iris Dexter}

Iris Dexter, 36, senior reporter on the weekly magazine Woman, looked the part of a stylish, sophisticated journalist, and her private life-married to one man, living with another-reinforced the slightly bohemian aura the public tended to attach to women journalists. She was born Iris Chapman Norton in the Sydney suburb of Haberfield in July 1907 to Wykes Strange Chapman Norton, engineer, and Eva Grace Norton, formerly Robey. When she was 15, Iris began work editing comics for the Sunday Times children's section and the following year she moved to editing work on a new weekly film magazine, Photoplayer, and filling in as editor of Theatre Magazine. In 1928, at age 21, she married Harry Norman Dexter, a sports journalist on the Sun, who was a member of a well-known family of racing writers, but the marriage was short-lived. In a 1935 legal case, Iris applied for a divorce on the grounds of constructive desertion, alleging she had been driven out of her home in December 1930 by her husband who was often drunk and had assaulted her on many occasions. Truth newspaper reported the case in salacious detail, delighting in having a 'pretty' young journalist and a racing writer as protagonists. It devoted headlines to Iris's evidence of her husband's violent physical attacks and her disclosure that soon after she left him she met cartoonist and commercial artist George Aubrey Jack Dolphin (Aubrey) Aria, ${ }^{55}$ with whom she had lived from March 1931. Aria gave evidence that he and Dexter wished to marry. The judge found constructive desertion proved but refused to use his discretion to grant a divorce citing the need to maintain morality. ${ }^{56}$ Dexter and Aria were not able to marry until 1951 after Harry Norman Dexter divorced Iris on the ground of desertion stating that she would not give up journalism for a domestic life. In the same year Harry Dexter, who was based in Melbourne as the Sydney Sun's sports and racing writer, married journalist Nancy Nugent whose column in the Melbourne Age, 'Nancy Dexter takes note', became well known for its discussion of feminist issues. ${ }^{57}$

\footnotetext{
54 Darryl McIntyre, Townsville at War 1942: Life in a Garrison City (Townsville, Qld: City of Townsville, 1992), 2. 55 'George Aubrey Aria', Design \& Art Australia Online, last updated 11 January 2015, www.daao.org.au/bio/ george-aubrey-aria/.

56 'Pretty Wife Tells of Husband's Treatment. Beat Her with a Razor Strop. Judge Puzzled in Strange Case', Truth, 5 May 1935, 17; 'Dismissed. Miss Iris Dexter Loses Divorce Case', Truth, 23 June 1935, 24.

57 Sybil Nolan, 'Dexter, Nancy Nugent (1923-1983)', Australian Dictionary of Biography, vol. 17, ed. Diane Langmore (Carlton, Vic.: Melbourne University Press, 2007), 315-16.
} 
At the time of her marriage in 1928, Iris, who was working as publicity manager for Hoyts Theatres Ltd, told an interviewer she believed women were especially suited to publicity work, she had grown up with the industry, understood it from a newspaper angle and was attuned to its newness. ${ }^{58}$ From 1929 to 1932 she had a regular film review column, 'At the pictures. Latest Talkies reviewed', in the Sydney Mail. During the 1930s when journalism jobs dried up, she worked in the advertising section of a department store, ${ }^{59}$ but continued contributing to newspapers and periodicals, and she listed her occupation as journalist on electoral rolls from the time she enrolled to her death. As a freelancer she contributed to Smith's Weekly, the Sunday Telegraph, the ABC Weekly, the Sun and the Guardian. In October 1940 Dexter was appointed to Woman and by 1943 she was described as the paper's ace reporter.

Woman was a down-to-earth magazine designed to appeal to housewives and working girls coping with the problems of day-to-day life who looked for escapist entertainment, succinctly written news stories and practical help. The fashion section often featured ways to enhance or remake an existing garment and cookery recipes made the most of limited supplies of rationed meat, butter and sugar. Slightly more daring than similar women's papers in its approach to social subjects, from 1941 Woman included a regular sex education page by Dr Norman Haire, a medical practitioner and sexologist, who wrote under the name of 'Dr Wykeham Terriss', and a column centred on relationships by left-wing writer and humanist Alan Marshall. Haire's articles discussed sex education, pregnancy, childbirth, gynaecological problems and venereal diseases more openly than some similar publications. His series on venereal diseases (VD) published early in 1943 reflected public concern particularly in wartime conditions and backed up the anti-VD propaganda campaigns by the federal and state governments. Nevertheless, they provoked strong criticism from some readers, including Mrs C.J. Gordon of Grafton, who also criticised Marshall's articles. Letters poured in to the Editor in defence of the two writers, ${ }^{60}$ and in the following issue the Editor took over the 'Wykeham Terriss' page to point to the advantage of open discussion of VD and the need for public education. A supporting comment by the Anglican Bishop of Goulburn, Dr E.H. Burgmann, was highlighted in a box in a prominent position on the page. ${ }^{61}$

Alan Marshall, whom the letter-writer coupled with Haire, offered readers of Woman commonsense advice on relationships in advance of conservative opinion, often encouraging women to be assertive not submissive, in his column 'Allan Marshall Says'. He was well known for his book I Can Jump Puddles, in which he described his experience of growing up crippled but undaunted following poliomyelitis contracted when he was 6. From the mid-1930s, Marshall became aligned with

58 'Bernice May' (Zora Cross), Australian Woman's Mirror, 11 September 1928, 10.

59 Isobel Wood, 'Margot Parker Was a Woman Ahead of Her Time', Sunday Telegraph, 7 April 19874, 25.

60 Woman, 8 March 1943, 14.

61 'Morality the Best Safeguard', Woman, 15 March 1943, 8. 
left-wing views, in 1938 being elected president of the Victorian Writers League that was regarded as a communist-front organisation. His left-wing political attitudes were popular during the period in World War II when Russia was an admired ally, but during the Cold War he came under frequent surveillance by the Australian Security and Intelligence Organisation. ${ }^{62}$

Iris Dexter's reports of the 1943 tour needed to differ from those in the dailies as by the time her articles were published, all their news value had disappeared. Instead of competing, she employed her more arresting style of writing and often centred her articles on a striking character. In the tropics, she wrote, the sun brought out 'the choking reek of furry weeds and the undergrowth steams like vegetables in a pot'. ${ }^{63}$ Near Uranquinty the camp was:

a sunstruck sweep of dust, rock, sagging gums, iron huts, camouflaged tents, and equipment. By night its lights slice the sky training on aircraft provided as targets ... The crew in training was wearing khaki drill skirts and shirts, fly veils, short socks, shoes so dusty they looked like suede, and AWAS felt hats discoloured around the bands with sweat. ${ }^{64}$

In north Queensland, Dexter found a suitable person to feature-a WAAAF squadron leader in charge of the largest concentration of servicewomen in Australia who rode around her scattered outposts on her bicycle. She described her striking personality in an article titled 'Starkie of the Waaaferies':

She is short, tanned as polished penny, can't be bothered with make-up, wears her pretty dark hair in a rumpled short cut, is outspoken, and has a galvanising direct approach to people and situations. In a climate that makes newcomers woolly-witted and apathetic, she is an energising reproach. ${ }^{65}$

Dexter also wrote a feature story about their tour leader Lynka Isaacson, who heard during the tour that her 22-year-old RAAF bomber pilot son, Peter Isaacson, had been awarded the Distinguished Flying Cross. 'His photographs went everywhere with us,' Dexter wrote. 'They were the first things unpacked and placed on bedside tables by his mother.' Peter Isaacson had survived 45 missions over European targets with RAF Bomber Command and had already been awarded the Air Force Cross and Distinguished Flying Medal, making him one of the most highly decorated airmen of World War II. ${ }^{66}$

62 John McLaren, 'Marshall, Alan (1902-1984)', Australian Dictionary of Biography, vol. 18, ed. Melanie Nolan (Carlton, Vic.: Melbourne University Press, 2012), 130-31.

63 Iris Dexter, 'Veterans Don't Giggle Now', Woman, 5 April 1943, 15.

64 'Iris Dexter Tells of the Women Who Go to War', Woman, 1 March 1943, 14-15.

65 Iris Dexter, "Starkie" of the WAAAFeries and the "Kids" She Commands', Woman, 19 April 1943, 16-17.

66 NAA A12372, R/35959/H, barcode 30697755, Isaacson, Peter Stuart; Iris Dexter, 'Making War a Family Affair', Woman, 12 April 1943, 15. 
When the group reached the tropics, Dexter turned to her invented character Frenzia Frisby in her 'Margot Parker' column to picture the journalists' adjustment to communal living in a variety of accommodation ranging from officers' quarters to makeshift barracks, tents and airport hangars:

One of the things about the tropics is mosquito nets. This has not gone unnoticed by all the people who are now pretty busy in the tropics. And you may be sure it has not entirely escaped the keen, inquiring mind of Frenzia Frisby ... In a revealing little brochure, entitled Through the North with a Remington ... which she is now preparing, she dwells pretty feelingly on the mosquito net in its various moods ... Frenzia Frisby says that this is the sort of thing that never gets into communiques. ${ }^{67}$

In another article, contemporaries could have identified the quirks and idiosyncrasies of Dexter's fellow travellers as 'Margot Parker' shared her conclusions 'on all this Girls Together stuff in the Quarters':

The idea is not to borrow the shoe polish, talcum powder, astringent lotion, soap flakes, pills, bobby-pins, cigarettes and cottonwool of others. At first. This powerful scrupulousness lasts for several days, after which everyone relaxes and becomes totally irresponsible and unselfish. It is all this comradeliness, this one for all and all for one spirit, which will, Frenzia thinks, be The Making of many a girl who is now effortlessly sleeping in her own bedroom, undisturbed by sleep-talkers, girls who've lost toothpaste caps, and those who hum 'Elmer's Tune' over and over and over again. ${ }^{68}$

Frenzia concluded that 'dormitory life fosters a spirit of Communism unguessed at by Those Accustomed to Privacy and Seclusion'.

\section{Gender discrimination}

A story that the women on tour would remember but which the censors would not have allowed past their blue pencils, as it could have disclosed to the enemy not only the parlous state of Queensland railway tracks but also the effect of the weather in delaying a trainload of troops destined for New Guinea, occurred on their journey by train from Brisbane to Townsville. The group departed on the night of 21 February for a journey of 2 nights and one day north on Queensland's narrow-gauge railway. The names of all stations on the journey had been removed as they had from railway stations, towns and streets throughout Australia to impede any enemy troops who might land. When the train was approaching Townsville it was stopped by major flooding and had to return to Bowen, 170 kilometres to the south, creating an emergency requiring all Lynka Isaacson's skill in arranging accommodation and effecting a rescue so the journalists could resume their tight itinerary.

67 Margot Parker, 'Reverie inside a Mosquito Net', Woman, 29 March 1943, 9.

68 Margot Parker, 'Let's All Be Girls Together', Woman, 5 April 1943, 9. 
Journalist Major Frederick Howard, public relations liaison officer in the Directorate of Public Relations, South West Pacific Area, ${ }^{69}$ described the women's dilemma in terms that convey the prejudice and contempt many male journalists harboured towards women journalists. In a letter to a fellow journalist he wrote: 'First of allthe Women ... they had to return to Bowen, where they spent two or three days of idleness with the Air Force. I only hope they behaved themselves in that Eveless Eden. ${ }^{70}$ In his diary he described the RAAF station where the women journalists were billeted as 'the most desolate' he had seen. 'Mournful quantities of rain' had turned the ground into a 'semi-swamp of dun earth and gravel' while the aircraft of the amphibian squadron stationed at Bowen were 'shabby and patched' adding to the general air of 'misery and decrepitude'. He concluded: 'No other place, surely, could be more sunk in warm, wet neglect. ${ }^{31}$ Then, returning to his denigration of the group pf women journalists, he wrote in a letter to the Assistant Director, PRO, Major R.J. (Reg) Denison: 'Three days there for Les Femmes must have meant hell for little Lt Isaacson. ${ }^{72}$

As the obvious rapport of Howard's correspondents indicates, most male journalists held similar opinions. Their views dated back to the emergence of women as competitors. In the nineteenth century, only a few women wrote for newspapers, the more fortunate being engaged to do a series of articles, but most were casual contributors with little security and paid per line. Most wrote for the general reader not specifically on women's topics. Louisa Atkinson's articles, published in the Sydney Morning Herald from 1860, the first long-running series by a woman to be published in a major Australian newspaper, were on the natural environment. The pioneer social reformer and writer Catherine Spence wrote on general interest issues including law and electoral reform, usually under a pseudonym. Feminist Alice Henry, the first woman journalist to be taken on the staff of a metropolitan newspaper and trained on the job, was a versatile general reporter.

Towards the end of the century, the situation of women who wrote for the press changed when editors began employing women to write and edit the newly emerging columns of women's news. Soon most women writers were employed in this work. For many this meant relegation to the social columns, graphically described in a Bulletin article as 'the deadly, dreary ruck of long dress reports and the lists of those who "also ran" at miscellaneous functions'. ${ }^{73}$ Women's sections on newspapers and periodicals built up small empires. Although women journalists were paid at the

69 NAA B883 Howard, Frederick James, VX128412, 6210898.

70 Australian War Memorial (AWM) PRO 3644. Lt Col Fred Howard Collection, Lt Colonel FJ Howard letter, 1 March 1943.

71 AWM PRO 3644 Lt Col Fred Howard Collection, Diary 22 February to 15 March.

72 AWM PRO 3644. Lt Col Fred Howard, Field HQ, New Guinea Force, to Major JR (Reg) Denison, Assistant Director PRO, 3 March 1943; David Dunstan, 'Howard, Frederick James (Fred) (1904-1984)', Australian Dictionary of Biography, vol. 17, ed. Diane Langmore (Carlton, Vic.: Melbourne University Press, 2007), 552-53.

73 Bulletin, 30 May 1912, 22. 
same rate as men, this was largely nullified as they were overwhelmingly employed on lower grades. Even women's page editors, responsible for considerable staffs and exercising far wider skills than middle-range male reporters were often graded lower than the industry average. The employment of women journalists in this confined field entrenched the view that not only was this work particularly suited to women, but also it was the only journalistic work they were capable of doing. ${ }^{74}$ This view of women journalists permeated the profession, as the correspondence of Frederick Howard indicates.

\section{After the tour}

The women stuck in Bowen were eventually rescued by Captain Henry Steel, a British Army liaison officer whom Howard described as 'an amiable rogue', who got several small planes to fly the group from Bowen to Cairns where they resumed their tour in reverse. The rescue turned out to be the start of a romance for Steel and one of the rescued journalists. In February 1944 at St Patrick's Cathedral, Melbourne, Patricia Knox married her rescuer, Henry Alfred Steel, by then a major. An officer in the British South Staffordshire Regiment, he had been deployed in 1940 in charge of British Public Relations at Malayan advanced headquarters and he had several narrow escapes from capture during the retreat down the Malay Peninsula. ${ }^{75}$ At the British surrender in February 1942, he and another journalist were the last newspapermen to leave Singapore. The small ship on which Steel escaped was bombed as it left, and he made his way from island to island to Australia where after he recuperated he was attached to the United Kingdom Liaison staff. After the Japanese surrender, he was the first newspaperman to return to Singapore, parachuting in on 4 September 1945. ${ }^{76}$ On 2 December 1947 he relinquished his commission in the British Army and became a public relations consultant in Melbourne where he and Patricia and their son lived. ${ }^{77}$

After her discharge from the AWAS, Lynka Isaacson had a brief spell as a fashion writer for Vogue until she was appointed women's page editor on the Argus, but increasingly she found the 'trivia of the women's pages' boring and she resigned in 1948. From May 1947 until it ceased in September the following year, Isaacson was honorary editor of Australian Jewish Outlook. Then, following a short period as owner/editor/reporter of the Dandenong Ranges News, she became editorial director of her son Peter Isaacson's rapidly expanding chain of suburban newspapers. While visiting Europe in 1961, the Melbourne Herald commissioned her to cover the trial

74 Clarke, 'Women in the Media', Companion, 495-98.

75 'Narrow Escape from Japanese in Hunt for News', News (Adelaide), 13 March 1942, 6; 'World War II Unit Histories \& Officers', www.unithistories.com.

76 Athole Stewart, 'First Man Back to Singapore', Argus, 6 September 1945, 16.

77 Warner, The Pathfinder, 168. 
of Adolph Eichmann who had been captured in Argentina and brought to Israel to face trial on war crimes and crimes against the Jewish people. She described the first day of the trial as 'a stupendous and unforgettable experience, heart-stirring in the extreme'. Just before Eichmann was sentenced to death in December 1961, she interviewed Mrs Eichmann in Linz, Germany. Isaacson was on her way back to Melbourne where she intended to set up an Australian-Israeli association when she died suddenly in Genoa on 23 January 1962 at the age of 62 from a heart condition. ${ }^{78}$

Iris Dexter finally achieved the aim of Australian women reporters in getting overseas but not until shortly after the war ended. ${ }^{79}$ Interviewed in Perth on her way to Asia to gather human interest stories from newly released civilian evacuees and Australian prisoners of war in Java and Singapore, she contrasted the ban on Australian women reporters with the numbers of American women correspondents who reported World War II overseas-127 American women reporters were accredited just to the war in the Pacific. ${ }^{80}$ Dexter continued to work for Woman until it ceased in 1951, then for its successor Woman's Day and as a feature writer for the Sydney Sun and the Sunday Sun. After he death in Sydney on 24 March 1974, it was her work as the 'wry, wise, sometimes astringent, always affectionate' Margot Parker that was remembered. ${ }^{81}$

Connie Robertson continued her long reign at the Sydney Morning Herald in the postwar era. As women returned to more traditional roles, the women's pages reverted to an emphasis on homemaking skills and the social circuit, although Robertson also introduced her readers to some overseas influences including Dior fashions, new homemaking ideas such as seagrass matting and exotic foods like moussaka. ${ }^{82}$ She retired in 1962 still editing women's pages that were a mirror of Australian society, slow to encompass change. When she died on 3 March 1964 at the age of 69 , the influence of the women's liberation movement was beginning to reverberate around the world to be reflected eventually in the demise of old-style women's pages. ${ }^{83}$

78 Patricia Clarke, 'Caroline (Lynka) Isaacson 1900-1962', Media Legends, 123.

79 Western Mail, 7 September 1945, 27.

80 Fay Anderson and Richard Trembath, Witnesses to War: The History of Australian Conflict Reporting (Carlton Vic.: Melbourne University Press, 2011), 118.

81 Isobel Wood, 'Margot Parker Was a Woman ahead of Her Time', Sunday Telegraph, 7 April 1974, 25.

82 Souter, Company of Heralds, 386.

83 Patricia Clarke, 'Constance Robertson', halloffame.melbournepressclub.com/article/constance-robertson. 


\section{Conclusion}

The tour by women journalists in 1943 led to a slight but temporary break in restrictions on women reporters. In October 1943, Australian journalist Lorraine Stumm, who represented a British newspaper at General MacArthur's headquarters in Brisbane, grabbed an opportunity to go to New Guinea to witness some of the first Allied air attacks on Rabaul. Australian Army Public Relations, unwilling to overrule MacArthur, took action once she reached Port Moresby and she got no further than watching Liberators take off at daybreak on their bombing mission. Following publicity arising from Stumm's trip to New Guinea, Australian Women's Weekly editor Alice Jackson was also allowed to visit New Guinea briefly. Although she was away only 7 days, she wrote many articles about Australian and United States hospitals and units. ${ }^{84}$ Army Public Relations, which may have been disappointed that she did not find it worthwhile competing for stories with other journalists on the 1943 tour, also offered Jackson an 'exclusive' tour of defence outposts in Western Australia designed to publicise service personnel serving at remote locations. ${ }^{85}$ Other women had to wait until the end of the war to get overseas. Many seized the opportunity and soon their stories from war-ravaged countries began appearing in the papers.

World War II opened opportunities for women in general reporting as male journalists left to join the armed services. Some retained their jobs after the war, but most of the gains were lost. By 1948 the ratio of female to male journalists on the Sydney Morning Herald's editorial staff had fallen to one in 13, appreciably lower than before the war. In the 1950s, women were not only a small percentage of the journalistic workforce but also most were still employed on the women's pages. An Argus journalist described the 1950s as an era when reporting innocuous social news was 'the bread and butter of women journalists' work'. ${ }^{86}$ In the 1960s, a few women's page editors ventured cautiously into controversial subjects such as equal opportunity in employment and a few women secured jobs reporting parliament and the courts. Widespread social changes and the influence of the women's liberation movement in the 1970s led to dramatic changes in the role of women in the media and the material they wrote for women. The old staples of women's reportage disappeared as the women's pages changed to more sexually neutral lifestyle sections with a wider agenda on social issues. Despite resistance by more conservative publications, by the end of the decade old-style women's pages had virtually disappeared..$^{87}$

84 Jeannine Baker, Australian War Reporters (Sydney: NewSouth Publishing, 2015), 111-12.

85 Denis O'Brien, The Weekly (Ringwood, Vic.: Penguin Books, 1982), 91.

86 Janette Conway, 'The '50s World of an Argus Woman Cadet', The Argus, ed. Usher, 61-2.

87 Clarke, 'Women in the Media', 497. 
This article has looked at the lives of 4 women journalists at a moment in time in the continuing history of women in the media. It reveals their status in 1943 in the journalistic hierarchy, it explains historic reasons for the gender-based discrimination against women journalists and it recounts the efforts women made to be accepted on an equal basis with male colleagues. It documents the disparaging attitude towards female journalists among males ranging from the Commonwealth minister who referred to them as 'womenfolk engaged on work of this nature' to the denigration of them and their work by Fred Howard, in civilian life chief leader writer on the Melbourne Herald and chair of a television program 'Meet the Press'. The attitudes they revealed were intrinsic to most male journalists of the era and were reflected in the Journalist, the monthly publication of the Australian Journalists Association.

The content of what the women wrote on the 1943 tour is now of historic interest only. It reveals, however, the assumptions they made, their style of journalistic writing when newspapers and periodicals were the main source of news, the gendered language that was accepted without question, and the aspects of life they thought worth recording. What they wrote reveals glimpses and insights into society and ordinary life in wartime Australia, nearly 80 years ago. 
This text is taken from Australian Journal of Biography and History: No. 4, 2020, published 2020 by ANU Press, The Australian National University, Canberra, Australia.

doi.org/10.22459/AJBH.04.2020.01 